$\underline{\text { Review Article }}$

\title{
MEDICINAL PLANTS OF NORTH-EAST REGION OF INDIA: A SMALL REVIEW
}

\author{
MRINMOY SHARMA*, BISWAJIT DAS \\ *Girijananda Chowdhury Institute of Pharmaceutical Science, Guwahati 781017, Assam \\ Email: mrinmoysarma67@gmail.com
}

Received: 21 Apr 2018, Revised and Accepted: 10 Jun 2018

\begin{abstract}
Assam is a state of the North Eastern part of India. There are varieties of plants distributed in various parts of the state. 50\% of India's entire plant biodiversity is contributed by the North Eastern States i.e., Manipur, Mizoram, Sikkim, Tripura including Assam. The Ministry of Environment and Forests (MoEF), Government of India in 1980s recorded two hundred and eighty-six (286) species of plants from Assam, used by the tribes of Assam.

The traditional system of medicine plays an important role in the healthcare of rural people for all types of ailments. The healing power of traditional herbal medicines has been realized and documented since Rigveda and Atharvaveda. Nearly $80 \%$ of the world populations rely on traditional medicines for primary health care, most of which involve the use of plant extracts.
\end{abstract}

Keywords: Medicinal plants, Assam, Phytochemical, Biodiversity

(C) 2018 The Authors. Published by Innovare Academic Sciences Pvt Ltd. This is an open access article under the CC BY license (http://creativecommons.org/licenses/by/4.0/) DOI: http://dx.doi.org/10.22159/ijcpr.2018v10i4.28471

\section{INTRODUCTION}

Most of the medicinal plants used by local people and tribes of the state of Assam are indigenous and are not known to the vast world of phytochemical science and research. The active ingredients and potent phytochemicals with promising pharmacological properties present in those plants are yet to be explored [1].

Maybe some lifesaving miracle drug formulation can be discovered from one or some of those indigenous plants of Assam which are being used with trust and confidence by thousands of people, the tribal and the villagers residing in Assam and can be a landmark in the world of pharmaceutical sciences and a blessing to mankind all over the globe [2].

\section{Assam-the peerless}

Assam words originate from Sanskrit word 'Asom' which means 'unparallel' or 'peerless' Assam is an evergreen state. Enormous medicinal plants and herbs have made her evergreen [3].

Assam derives its name from the 'Ahoms'-who ruled the state for $600 \mathrm{y}$ till the British came to India. Assam is a state of ' $\mathrm{Y}$ ' shaped. Among the three major physical regions of Assam, the Brahmaputra river valley is the largest followed by the Barak River valley in the south, and the hilly region between Meghalaya (to the west) and Nagaland and Manipur (to the east).

The diverse topology of the state Assam provides a platform for diverse biodiversity of Assam. The climatic condition of Assam is primarily hot and humid with sufficient precipitation around the year. The main profession of people of the state of Assam is agriculture. The principal food crop is rice and the principal cash crop includes tea, jute, cotton, etc. Major fruits found growing in the state of Assam are guava, banana, jackfruit, pineapple, blackberry, sugarcane, orange, mango etc. Assam is well known for sericulture. Exclusive varieties of silk i.e., Endi, Muga, Tassar, etc. are produced by Assam. Muga silk is produced only by Assam in the world [4].

\section{Plant biodiversity of assam}

India is one among the twenty-five 'mega-biodiverse' regions of Earth. Assam is a part of the Eastern Himalayan Biodiversity of India.
The geographical area of Assam is $78,438 \mathrm{~km}^{2}$ of which $35.48 \%$ is a forest. The forest in Assam can be classified as

- Tropical Wet Evergreen Forests

- Tropical Semi Evergreen Forests

- Tropical Moist Deciduous Forests

- Sub-tropical Broadleaf Hill Forests

- Sub-tropical Pine Forests

- Littoral and Swamp Forests

- Grassland and Savannahs.

Golaghat, Jorhat, Sibsagar, Tinsukia, Dibrugarh etc are fall under Tropical Wet Evergreen Forests. Hollong (Dipterocarpus macrocarpus) the tallest tree of Assam also known as the 'State Tree' is found in these forests.

Hallangapar, Kakoi, Nauduar, Batasipur, Abhoypur, Dilli, Dhansiri, Kholahat, Mayong, Garbhanga, Rani, Mahamaya, Guma, Dohalia, Singla, Haltugaon, Kachugaon, Gali, Pobha, Ranga etc are fall under Tropical Semi Evergreen Forests.

Moist deciduous forests are distributed in the Districts of Nagaon, Morigaon, Kamrup, parts of Nalbari and Barpeta, Darrang, Dhubri, Kokrajhar and Goalpara. Sal (Shorea robusta) is the primary tree found in moist deciduous forests of Assam along with other species of trees. Terminalia is also abundant.

In the districts of Karbi Anglong and North Cachar Hills are found the Sub-tropical Pine forests and Sub-tropical Broad Leaf Hills forests. Alseodaphne petiolaris (Ban-hanwalu), Cleidon speciflorum, Antidesma bunius, Betula alnoides, etc. are the various species found. Grassland and Savannahs constitute the vegetation in Kaziranga National Park, Orang, Sonai-Rupai, Laokhowa, Pobitora, Barnadi, Burachapori, Dibru-Saikhowa Wildlife Sanctuaries and to some extent in Manas National Park [5] 
Table 1: Some medicinal plants of Assam, their common name, compounds present and medicinal use [6-10]

\begin{tabular}{|c|c|c|c|c|}
\hline $\begin{array}{l}\text { S. } \\
\text { No. }\end{array}$ & Scientific name & Vernicular name & $\begin{array}{l}\text { Family and } \\
\text { distribution }\end{array}$ & Uses \\
\hline 1 & Vanda coerulea & $\begin{array}{l}\text { Bhatou } \\
\text { Phul (Assamese) }\end{array}$ & $\begin{array}{l}\text { Orchidaceae India: } \\
\text { Assam, Arunachal } \\
\text { Pradesh }\end{array}$ & $\begin{array}{l}\text { Eye drops for the treatment of Glaucoma. Catract and } \\
\text { blindness }\end{array}$ \\
\hline 2 & $\begin{array}{l}\text { Renanthera } \\
\text { imschootiana }\end{array}$ & Red Vanda & $\begin{array}{l}\text { Orchidaceae } \\
\text { Assam }\end{array}$ & Gonorrhoea, control eye sores \\
\hline 3 & $\begin{array}{l}\text { Rauvolfia } \\
\text { serpentina }\end{array}$ & Chota chand & $\begin{array}{l}\text { Apocynaceae } \\
\text { Assam, }\end{array}$ & Sedation, hypertension, brodyeardia, myosis, ptosis, tremors \\
\hline 4 & $\begin{array}{l}\text { Aquilaria } \\
\text { mallaccensis }\end{array}$ & Agarwood & $\begin{array}{l}\text { Thymelaeaceae } \\
\text { Assam }\end{array}$ & $\begin{array}{l}\text { Wood is stimulant, tonic, aphrodisiac, carminative, astringent, } \\
\text { also used in diarrhoea, constipation, vomiting and snakebite. }\end{array}$ \\
\hline 5 & Hibiscus manihot & USIPAK (Assamese) & Malvaceae Assam & Tuberculosis, anti-diabetic \\
\hline 6 & Abies spectabilis & $\begin{array}{l}\text { Talishpatra (Assamese, } \\
\text { Bengali) }\end{array}$ & $\begin{array}{l}\text { Pinaceae } \\
\text { Assam }\end{array}$ & Asthma, bronchitis, Carminative, Expectorant, Diuretic \\
\hline 7 & Abroma augusta & Bon-kopah (Assamese) & Sterculiaceae Assam & Diabetes and headache \\
\hline 8 & Arbus precatorius & Latumoni, Rati (Assamese) & Fabceae Assam & Diuretic, emetic, aphrodisiac \\
\hline 9 & Abutilon indicum & Pera-petari (Assamese) & Malvaceae Assam & Anti-inflamatory, astringent, Diuretic \\
\hline 10 & $\begin{array}{l}\text { Acacia } \\
\text { polyacantha }\end{array}$ & Samaidh (Assamese) & $\begin{array}{l}\text { Mimosaceae } \\
\text { Assam }\end{array}$ & Bitter, astringent, anthelmintic \\
\hline 11 & Acalypha indica & $\begin{array}{l}\text { Mukuta-manjari } \\
\text { (Assamese) }\end{array}$ & $\begin{array}{l}\text { Euphorbiaceae } \\
\text { Assam }\end{array}$ & Burns,scabies, syphilis and centiped bites \\
\hline 12 & $\begin{array}{l}\text { Achyranthes } \\
\text { aspera }\end{array}$ & Hati-huria (Assamese) & $\begin{array}{l}\text { Amaranthaceae } \\
\text { Assam }\end{array}$ & Dysentry, piles ulcer, diuretic \\
\hline 13 & Acorus calmus & Bos (Assamese) & Araceae Assam & Chronic diarrhoea and dysentry \\
\hline
\end{tabular}

\section{CONCLUSION}

Assam consist of rich varieties of medicinal plants and herbs. Most of those plants and their medicinal uses are known only to the inhabitant and the tribes residing in various parts of Assam. The active ingredients present in these plants may be used for designing some new drugs and pharmaceutical agents which can pave some new alleys in the world of pharmaceutical sciences and be a blessing for mankind. Plant-derived pharmaceutical formulations used to treat diseases.

Alternative medicine is better than our conventional allopathic medication and can enhance the impact of conventional drugs if used properly. Natural product derived from plants may be do not have any side effects till date if used in a specific dose. Some of the medicinal plants work unbelievably in certain diseased conditions according to the tribal people of Assam. Maybe while hunting for drugs in laboratories for certain deadly diseases day and night, researchers and scientists are missing some miraculous and potent phytochemical constituents which could be modified for formulating the drug, which are present in the plants grown in wild and ignorance on the roadside, backyards and valleys of Assam.

\section{AUTHORS CONTRIBUTIONS}

All the author have contributed equally

\section{CONFLICT OF INTERESTS}

Author declare that they do not have any conflict of interest

\section{REFERENCES}

1. Mao AA, Hynniewta TM. Floristic diversity of North East. India J Assam Sci Soc 2000;41:255-66.

2. Hynniewta TM. Ethnobotanical investigations of some tribes of Arunachal Pradesh. Proc Second Annual workshop on MAB Project; 1984. p. 83-7.

3. Bhattacharya PC, Muzumder R, Sarmah GCD. Rare medicinal plants of Assam. Ancient Sci Life 1991;10:234-8.

4. Ghosh D, Parida P. Medicinal plants of Assam, India: a mini review. Int J Pharmacol Pharm Sci 2015;2:5-10.

5. Mao AA, Hynniewta TM, Sanjappa M. Plant wealth of Northeast India with reference to ethnobotany. Indian J Traditional Knowledge 2009;8:96-103.

6. Mensah AY, Bonsu AS, Fleischer TC. Investigation of the bronchodilator activity of abrus precatorius. Int J Pharm Sci Rev Res 2011;6:9-13.

7. Taid TC, Rajkhowa RC, Kalita JC. A study on the medicinal plants used by the local traditional healers of Dhemaji district, Assam, India for curing reproductive health-related disorders. Adv Appl Sci Res 2014;5:296-301.

8. Das NJ, Saikia SP, Sarkar S, Devi S. Medicinal plants of NorthKamrup district of Assam used in the primary healthcare system. Indian J Traditional Knowledge 2006;5:489-93.

9. Hazarika R, Abujam SS, Neog B. Ethnomedicinal studies of common plants of Assam and Manipur. Int J Pharm Biol Arch 2012;3:809-15.

10. Lai Y, Lim YY, Kim KH. Blechnum Orientale linn-a fern with potential as an antioxidant, anticancer and antibacterial agent. BMC Complementary Altern Med 2010;10:15. 